DOI: https://doi.org/10.31933/dijemss.v2i4

Received: 15March 2021, Revised: 15 April 2021, Publish: 22 April 2021

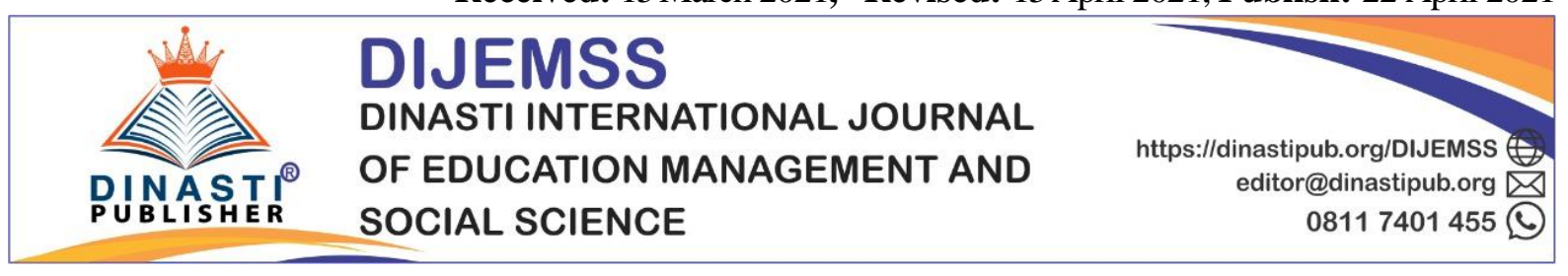

\title{
THE INFLUENCE OF ORGANIZATIONAL COMMITMENT, CAREER DEVELOPMENT AND WORK ENVIRONMENT ON EMPLOYEES' JOB SATISFACTION (CASE STUDY AT PT. MAP SURVEILLANCES)
}

\author{
Wulan Istia Fatmawati ${ }^{1}$, Chaerudin Chaerudin ${ }^{2}$ \\ 1) Universitas Mercu Buana, Jakarta, Indonesia, fwulanistia16@ gmail.com \\ ${ }^{2)}$ Universitas Mercu Buana, Jakarta, Indonesia, chaerudin18@ gmail.com
}

\section{Corresponding Author: Wulan Istia Fatmawati}

Abstract: This research aims to learn further regarding the impact caused by Organizational Commitment, Career Development and Work Environment on Employee Job Satisfaction either partially or simultaneously. The research population amounted to 140 respondents with a sample filtered of 95 respondents who were employees at Head Office and Site Office of PT. Map Surveillances. The quantitative descriptive research method used multiple linear regression analysis through the version 22 SPSS (Statistical Package for the Social) application program. The results showed that Organizational Commitment, Career Development and Work Environment had a positive and significant impact on Job Satisfaction both partially and simultaneously.

Keywords: Organizational commitment, career development, work environment, job satisfaction.

\section{INTRODUCTION}

Humans, in this case it refers to employees, plays an crucial part in organization management to reached the business goals and it purposes and as the main incitation of the company. When the organization has a high commitment to its employees, for example, by creating a comfortable work situation and providing career opportunities to employees in which to achieve organizational goals. The employees' job satisfaction and dissatisfaction will have a huge impact towards the organization and its employees themselves, through considering several job satisfaction factors, namely organizational commitment, career development and work environment.

The various results from job satisfaction research which obtained from various sources shows that the level of job satisfaction on employees in India is in the highest ranks by $88 \%$. While, the level of job satisfaction in Indonesia is only 17\%. PT. Map Surveillances is one of the private mining companies in Indonesia, with a total of 140 employees. And the results from the pre-survey related to Job satisfaction towards its 20 employees by considering the indicators of employee job satisfaction variables, which could be explained through table below: 
Table 1. Pre-Survey of Employees' Job Satisfaction

\begin{tabular}{clccc}
\hline Variable & \multicolumn{1}{c}{ Indicator } & Satisfied & Dissatisfied & Total \\
\hline \multirow{2}{*}{ Organizatonal } & Affective Commitment & $40 \%$ & $60 \%$ & $100 \%$ \\
Commitment & Normative Commitment & $48 \%$ & $53 \%$ & $100 \%$ \\
& Continuous Commitment & $38 \%$ & $63 \%$ & $100 \%$ \\
\hline \multirow{2}{*}{ Career Development } & Career Management & $53 \%$ & $48 \%$ & $100 \%$ \\
& Career Planning & $38 \%$ & $63 \%$ & $100 \%$ \\
\hline \multirow{2}{*}{ Work Environment } & Physical Environment & $75 \%$ & $25 \%$ & $100 \%$ \\
& Non-physical Environment & $83 \%$ & $18 \%$ & $100 \%$ \\
\hline \multirow{5}{*}{ Job Satisfaction } & Job Itself & $48 \%$ & $53 \%$ & $100 \%$ \\
& Salary & $40 \%$ & $60 \%$ & $100 \%$ \\
& Promotion & $50 \%$ & $50 \%$ & $100 \%$ \\
& Supervision & $70 \%$ & $30 \%$ & $100 \%$ \\
& Co-workers & $65 \%$ & $35 \%$ & $100 \%$ \\
\hline
\end{tabular}

These outcome has shown that: 1) The low of job satisfaction on the employees has occurred in the salary factor as many as $60 \%$ with the highest percentage and also the job factor itself as many as $52 \%$ in the pre-survey data. 2) The low of job satisfaction on the employees has occured in organizational commitment factors, both continuous commitment by $62 \%$, effective commitment by $60 \%$ and normative commitment as many as $53 \%$. 3) The low of job satisfaction on employees has occured in career development factors, which is by $62 \%$ of employees were feeling dissatisfied with the employee career planning. 4) The high of job satisfaction on employees through physical work environment factors reached $75 \%$ and non-physical work environment was 83\%. 5) An indication which tell that the employee dissatisfied with the company caused by the company's inconsistency with the policies that they're made.

From the previous research conducted by Prastowo (2015) in his research shows that career development had a negative and significant impact on job satisfaction. Furthermore, the research of Dhermawan et al. (2012) defines that the work environment did not have a significant impact on job satisfaction.

According to the pre-survey results and the research gap from previous research, further research is needed on employees' job satisfaction by investigating further related to organizational commitment, career development and work environment satisfaction by examining these variables in order to identify which variables that have the most influence on employees' job satisfaction.

\section{LITERATURE REVIEW Organizational Commitment}

Robbins \& Judge (2015) argues that organizational commitment could defines as an situation in which an employee is willing to carry out the organizational goals and desired to maintain their positions in the organization. Furthermore, Robbins \& Judge (2015) viewed this organizational commitment as a work attitude. Because it reflects of someone's feelings (like or dislike) towards the organization where they work, an individual orientation towards the organization which includes loyalty, identification and involvement. So, the 
organizational commitment has orientation on the active correlation between personals and their organizations. This relations orientation has results in the individual (employee) that willing to give anything and that anything reffers to support in order to achieve the organizational goals. The Dimensionons of organizational commitment were include affective commitment, normative commitment and continuous commitment.

\section{Career Development}

According to Simamora (2001) in Widodo (2014:107) career development is a sequence of activities related to work, someone's behavior towards values and ambition for career advancement. Siagian (2015:215) defines that career development is a decision which made recently about what to do next and establish a career plan by taking certain steps to realized that career plan. Various steps could be taken by initiative of the workers themselves, but it could be take as in form of activities which sponsored by the organization or a combination of these two. The career development Dimensionon were includes career opportunities and career planning.

\section{Work Environment}

According to Sedarmayanti (2017) in Burhannudin et al. (2019:194) work environment could be define as a forum for various groups in which there is a supporting structure to achieve company goals based on the company's vision and mission. According to Nitisemito (2010:183) in Prasetyo et al (2021), work environment is everything surround by the employees which affects them in accomplished their assigned tasks. According to Sutrisno (2010) work environment is all work facilities and infrastructure around employees in carrying out work which has an impact towards the implementation of work itself. Work environment were includes both physical and non-physical. According to some of these opinions, it could be interpreted that work environment is an condition of the workplace both physical and non-physical which could create a pleasant, comfortable and safe feeling on employees and plays huge role on employees in accomplish their tasks.

\section{Job Satisfaction}

Job satisfaction ratings could be describe as how comfortable or uncomfortable a person is, or feels satisfied or dissatisfied at work (Rivai \& Sagala, 2010:856). Robbins \& Judge (2015) define job satisfaction as a positive feeling at a work, which has an impact on the result from various aspects of the job. According to Locke in Luthans (2006:243) job satisfaction is a someone's positive emotional state as the result from appreciation of something that they have done. Elicited from these opinions, it could be interpreted that job satisfaction is an collection of feelings that experienced by someone towards their job, whether they are satisfied with the situation and conditions of work so as to create perceptions which reflects on their attitudes and behavior at work. The Dimensionons from job satisfaction were include that job itself, salary, promotion opportunities, supervision and co-workers. 


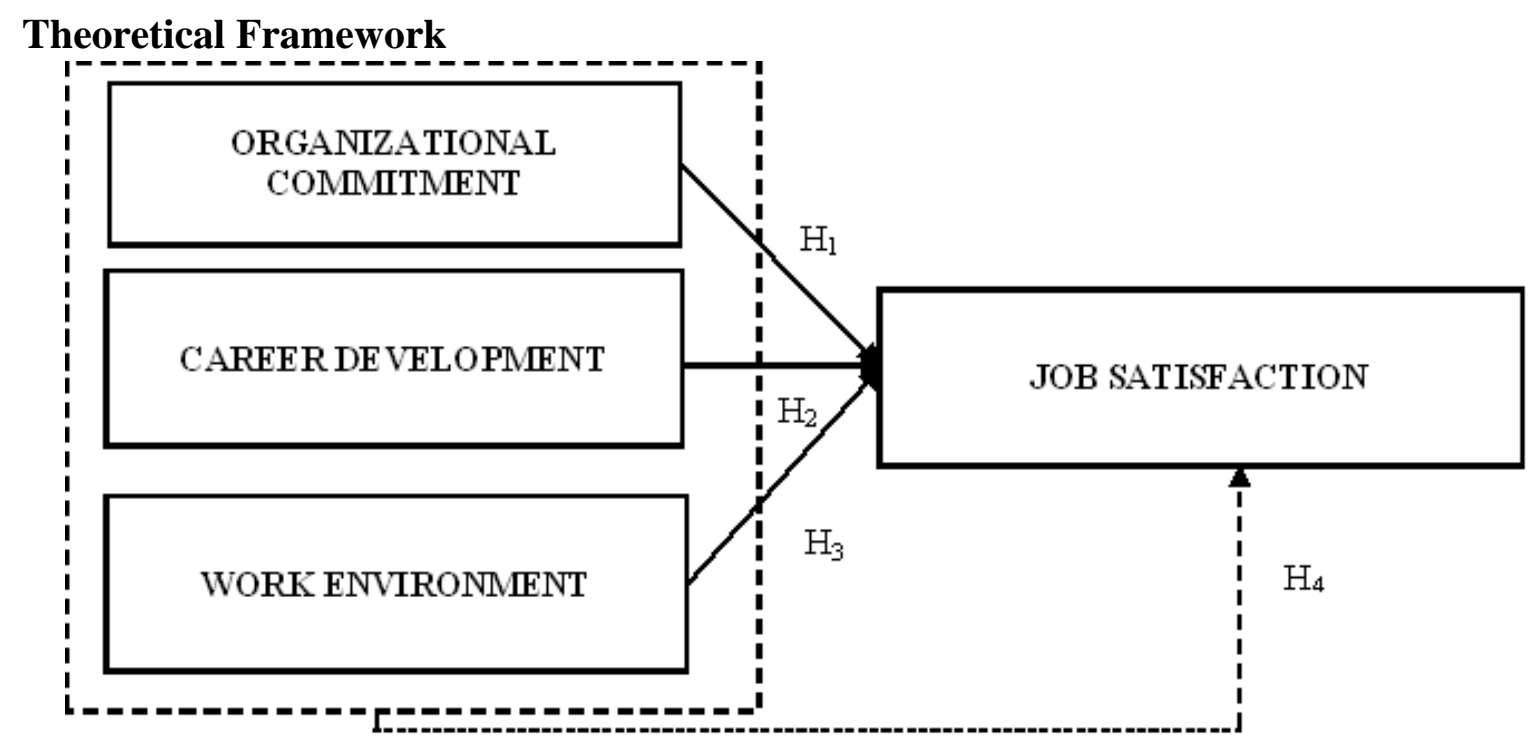

Figure 1. Theoretical Framework

\section{Hypothesis}

According to the development of the theoretical framework above, the hypothesis in this research could be explained as follows:

H1: Organizational Commitment affects Job Satisfaction

H2: Career Development affects Job Satisfaction

H3: Work Environment affects Job Satisfaction

H4: Organizational Commitment, Career Development and Work Environment simultaneously affects Job Satisfaction.

\section{RESEARCH METHODOLOGY}

The research design used was quantitative with causal methods to reveal the causal relations on each variables. The independent variables in this research are organizational commitment, career development and work environment. While the dependent variable is job satisfaction. The research population were all employees at PT. Map Surveillance, which amounted to 140 people. Based on this population, the number of samples earned was 104 employees of PT. Map Surveillance, but because 9 samples were not feasible to analyzed, then the sample left only 95 people. This research used several techniques in collected the data were included questionnaires, interviews, documentation and observation. Meanwhile, the data analysis method that used was multiple linear regression analysis to examine those hypothesis.

\section{RESULT AND DISCUSSION Instrument Test}

Table 2 shows that the Pearson Correlation value from all question items (indicators) in the variables of Job Satisfaction, Organizational Commitment, Career Development and Work Environment met the validity requirements, which are above the value of 0.3 so the questionnaire used was feasible to be processed as research data. 
Table 2. Validity Test Results

\begin{tabular}{|c|c|c|c|c|}
\hline No & Variable & Item & Pearson Correlation & Status \\
\hline \multirow{10}{*}{1} & \multirow{10}{*}{$\begin{array}{c}\text { Job Satisfaction } \\
(\mathrm{Y})\end{array}$} & Y 1.1.1 & 0,327 & Valid \\
\hline & & Y 1.1 .2 & 0,455 & Valid \\
\hline & & Y 1.2 .1 & 0,356 & Valid \\
\hline & & Y 1.2 .2 & 0,371 & Valid \\
\hline & & Y 1.3 .1 & 0,550 & Valid \\
\hline & & Y 1.3 .2 & 0,644 & Valid \\
\hline & & Y 1.4 .1 & 0,623 & Valid \\
\hline & & Y 1.4 .2 & 0,561 & Valid \\
\hline & & Y 1.5 .1 & 0,331 & Valid \\
\hline & & Y 1.5 .2 & 0,472 & Valid \\
\hline \multirow{6}{*}{2} & \multirow{6}{*}{$\begin{array}{l}\text { Organizational } \\
\text { Commitment } \\
\text { (X1) }\end{array}$} & $\mathrm{X} 1.1 .1$ & 0,566 & Valid \\
\hline & & $\mathrm{X} 1.1 .2$ & 0,756 & Valid \\
\hline & & $\mathrm{X} 1.2 .1$ & 0,382 & Valid \\
\hline & & $\mathrm{X} 1.2 .2$ & 0,577 & Valid \\
\hline & & $\mathrm{X} 1.3 .1$ & 0,438 & Valid \\
\hline & & $\mathrm{X} 1.3 .2$ & 0,528 & Valid \\
\hline \multirow{4}{*}{3} & \multirow{4}{*}{$\begin{array}{c}\text { Career } \\
\text { Devel opment } \\
\text { (X2) }\end{array}$} & $\mathrm{X} 2.1 .1$ & 0,525 & Valid \\
\hline & & $\mathrm{X} 2.1 .2$ & 0,331 & Valid \\
\hline & & $\mathrm{X} 2.2 .1$ & 0,565 & Valid \\
\hline & & $\mathrm{X} 2.2 .2$ & 0,567 & Valid \\
\hline \multirow{4}{*}{4} & \multirow{4}{*}{$\begin{array}{c}\text { Work } \\
\text { Environment } \\
\text { (X3) }\end{array}$} & $\mathrm{X} 3.1 .1$ & 0,345 & Valid \\
\hline & & $\mathrm{X} 3.1 .2$ & 0,319 & Valid \\
\hline & & $\mathrm{X} 3.2 .1$ & 0,429 & Valid \\
\hline & & $\mathrm{X} 3.2 .2$ & 0,445 & Valid \\
\hline
\end{tabular}

Table 3 shows that all variables have met the reliable requirements, which is the Cronbach's Alpha value $>0.6$, thus it could be interpreted that those indicators in these variables were reliable and could be discuss further to sort of the issues on this research.

Table 3. Reliability Test Results

\begin{tabular}{clcl}
\hline No & \multicolumn{1}{c}{ Variable } & Cronbach's Alpha & Status \\
\hline 1 & Job Satisfaction (Y) & 0.811 & Reliable \\
2 & Organizational Commitment (X1) & 0.780 & Reliable \\
3 & Career Development (X2) & 0.797 & Reliable \\
4 & Work Environment (X3) & 0.676 & Reliable \\
\hline
\end{tabular}

\section{Classic Assumption Test}

The Kolmogrov-Smirnov test result shows that the Asymp.Sig. (2-tailed) in Table 4 amounted to 0.200 . The sig value was $0.200>0.05$, then the residual value data has follows the normal distribution. Thus it could be said based on the unstandarized residual normality test results, it is found that the data was normally distributed. 
Table 4. Normality Test Results

One-Sample Kolmogorov-Smirnov Test

\begin{tabular}{llr}
\hline & & Unstandardized Residual \\
\hline N & & 95 \\
Normal Parameters ${ }^{\mathrm{a}, \mathrm{b}}$ & Mean &, 0000000 \\
& Std. Deviation &, 32709783 \\
Most Extreme Differences & Absolute &, 074 \\
& Positive &, 074 \\
& Negative &,- 049 \\
Test Statistic & &, 074 \\
Asymp. Sig.(2-tailed) & &, $200^{c}$ \\
\hline
\end{tabular}

Table 5 shows that in the independent variable such as Organizational Commitment, Career Development and Work Environment, the VIF (Value Inflation Factor) value was less than 10 and the tolerance value was above 0.1. Thus, it can be interpreted that the multicollinearity did not occurred. Meaning that there is no correlation between the independent variables in this regression model.

Table 5. Multicollinearity Test Results

\begin{tabular}{lll}
\hline \multirow{2}{*}{ Model } & \multicolumn{2}{c}{ Collinearity Statistics } \\
\cline { 2 - 3 } & Tolerance & VIF \\
\hline \multirow{2}{*}{1 (Constant) } & & \\
\cline { 2 - 3 } Organizational Commitment & 0,809 & 1,236 \\
\cline { 2 - 3 } Career Development & 0,823 & 1,216 \\
\cline { 2 - 3 } Work Environment & 0,716 & 1,397 \\
\hline
\end{tabular}

Table 6 shows that the sig value from the variable of Organizational Commitment, Career Development and Work Environment was $>0.05$ so it could be consider that there is no heteroscedasticity in this regression model.

Table 6. Heteroscedasticity Test Results

\begin{tabular}{|c|c|c|c|c|c|c|}
\hline \multirow{2}{*}{\multicolumn{2}{|c|}{ Model }} & \multicolumn{2}{|c|}{$\begin{array}{l}\text { Unstandardized } \\
\text { Coefficients }\end{array}$} & \multirow{2}{*}{$\begin{array}{c}\text { Standardized } \\
\text { Coefficients } \\
\text { Beta }\end{array}$} & \multirow{2}{*}{$\mathrm{t}$} & \multirow{2}{*}{ Sig. } \\
\hline & & B & $\begin{array}{l}\text { Std. } \\
\text { Error }\end{array}$ & & & \\
\hline \multirow{4}{*}{1} & (Constant) &,- 069 & 136 & &,- 504 &, 616 \\
\hline & Organizational Commitment & 006 & 036 & 018 & 160 & 873 \\
\hline & Career Development & 051 & 034 & 167 & 1,501 & 137 \\
\hline & Work Environment & 049 & 041 & 141 & 1,181 & 241 \\
\hline
\end{tabular}

\section{Hypothesis Examination}

Quoted from the results of multiple linear regression, these following regression equation which could be obtained is: $\mathrm{Y}=1.014+0.463\left(\mathrm{X}_{1}\right)+0.113\left(\mathrm{X}_{2}\right)+0.096\left(\mathrm{X}_{3}\right)$.

1) For organizational commitment it is found that the $t$ value was $7.469>t$ table 1.98638

with Sig value for the influence of the Organizational Commitment variable (X1) on Job Satisfaction variable $(\mathrm{Y})$ was $0.000<0.05$, then Ho was rejected. So it could be 
interpreted that organizational commitment variable had a positive and significant impact towards employees' job satisfaction at PT. Map Surveillances.

2) For career development it is found that the $t$ value was $2.716>t$ table 1.98638 with Sig value for the influence of Career Development variable (X2) on Job Satisfaction variable (Y) was $0.048<0.05$, then Ho was rejected. So it could be interpreted that career development variable had a positive and significant impact on employees' job satisfaction at PT. Map Surveillances.

3) For work environment it is found that the t value was $1.998>t$-table 1.98638 with Sig value for the influence of Work Environment variable (X3) on Job Satisfaction variable (Y) was $0.018<0.05$, then Ho was rejected. So it could be interpreted that work environment variable had a positive and significant impact on employees' job satisfaction at PT. Map Surveillances.

Table 7. The Results of Multiple Linear Regression Analysis

\begin{tabular}{|c|c|c|c|c|c|c|}
\hline \multirow{2}{*}{\multicolumn{2}{|c|}{ Model }} & \multicolumn{2}{|c|}{$\begin{array}{c}\text { Unstandardized } \\
\text { Coefficients }\end{array}$} & \multirow{2}{*}{$\begin{array}{c}\text { Standardized } \\
\text { Coefficients }\end{array}$} & \multirow{2}{*}{$\mathrm{t}$} & \multirow{2}{*}{ Sig. } \\
\hline & & B & $\begin{array}{l}\text { Std. } \\
\text { Error }\end{array}$ & & & \\
\hline \multirow{4}{*}{1} & (Constant) & 1,014 & 235 & & 4,317 &, 000 \\
\hline & Organizational Commitment & 463 & 062 & 603 & 7,469 & 000 \\
\hline & Career Development & 113 & 059 & 153 & 2,716 & 048 \\
\hline & Work Environment & 096 & 071 & 115 & 1,998 & 018 \\
\hline
\end{tabular}

According to the ANOVA analysis results, it shows that the variables of Organizational Commitment (X1), Career Development (X2) and Work Environment (X3), has the F-count value was $32.925>$ F-table 2.70, then Ho was rejected. So it could be interpreted that these variables of Organizational Commitment, Career Development and Work Environment simultaneously affects Job Satisfaction. While its significance value was $0.000<0.05$, then Ho was rejected, which means that those variables (Organizational Commitment, Career Development and Work Environment) has a positive and significant impact towards Job Satisfaction of PT. Map Surveillances.

Table 8. F-Test Results

\begin{tabular}{|c|c|c|c|c|c|c|}
\hline \multicolumn{7}{|c|}{ ANOVA $^{\mathrm{a}}$} \\
\hline & del & Sum of Squares & df & Mean Square & $\mathrm{F}$ & Sig. \\
\hline \multirow{3}{*}{1} & Regression & 10,917 & 3 & 3,639 & 32,925 & $.000^{6}$ \\
\hline & Residual & 10,057 & 91 &, 111 & & \\
\hline & Total & 20,974 & 94 & & & \\
\hline
\end{tabular}

According to the test results, it is found that the coefficient of determination $\left(\mathrm{R}^{2}\right)$ was 0.52. This illustrated that these three independent variables, namely Organizational Commitment (X1), Career Development (X2) and Work Environment (X3) simultaneously describe the variation in Job Satisfaction (Y) by $52 \%$ while the remaining of $48 \%$ was explained by other factors outside the research variables. 
Table 9. The Results from Coefficient of Determination Test

\begin{tabular}{rrrrr}
\hline \multicolumn{5}{c}{ Model Summary } \\
\hline Model & $\mathrm{R}$ & $\begin{array}{c}\mathrm{R} \\
\text { Square }\end{array}$ & Adjusted R Square & \multirow{2}{*}{ Std. Error of the Estimate } \\
\hline 1 &, $721^{\mathrm{a}}$ &, 520 &, 505 &, 332446 \\
\hline
\end{tabular}

\section{CONCLUSION AND SUGGESTION}

\section{Conlusion}

Conclusion according to the research results and discussion as previously described, several conclusions could be obtained as follows:

1) Organizational commitment had a positive and significant impact on employees' job satisfaction at PT. Map Surveillances. The highest value of the relations between dimensions was occured in the dimension of continuous commitment to promotion opportunities.

2) Career development had a positive and significant impact on employees' job satisfaction at PT. Map Surveillances. The highest value of the relations between dimensions was occured in the dimension of career management to promotion opportunities.

3) Work environment had a positive and significant impact on employees' job satisfaction at PT. Map Surveillances. The highest value of the correlation between dimensions was occured in the dimension of the non-physical work environment to supervision.

4) Organizational commitment, career development and work environment together (simultaneously) had a positive and significant impact on Job Satisfaction by $52 \%$.

\section{Suggestion}

Elicited from the conclusions which have been mentioned above, there are several suggestions that could be used as consideration to improve the job satisfaction, namely as follows:

1) In order to increase the employees' job satisfaction through organizational commitment, where it is found that the highest correlation value occured in the dimension of continuous commitment to promotional opportunities, So it is advisable for companies to creates an improvements in the aspect of promotional opportunities, such as the company is expected to capable to provide a fair opportunities based on competence and potential of each employee to get that promotion with hoped that employees would have an emotional attachment which turn into loyalty to the company.

2) In order to increase the employees' job satisfaction through career development, where it is found that the highest influential correlation value occured in the correlation between career management and promotion opportunities, So it is advisable for companies to provide opportunities for each employee to gained an educational and training opportunities, Certainly with guidance and direction from the right leaders by focusing on the company's needs about the talents and abilities of employees. Company involvement could be done through career education, career information, career counseling and providing career counseling to help the employees set up their career goals and find suitable career paths. 
3) In order to increase the employees' job satisfaction through work environment, where it is found that the most influential correlation value occured between non-physical work environment to supervision, which is by providing a system of supervision, guidance and direction which carried out directly by the right leader, one of that is by providing guidance and direction when employees experiencing difficulties at work so the employees would be able to complete work accordingly with measured manner and also supported by co-workers who are harmonious and capable to work well together.

4) And it is hoped that this research could be useful enough as a reference for managing human resources in the company in an efforts to enhance the employees' job satisfaction from the view of the aspects of organizational commitment, career development and work environment. As for further research, the results of this research was proven that the coefficient of determination was $52 \%$, so there are still has possibility for doing further research by upgrading this research through adding another variables which relates to the employees' job satisfaction.

\section{REFERENCES}

Burhannudin, B., Zainul, M., \& Harlie, M. (2019). Pengaruh Disiplin Kerja, Lingkungan Kerja, dan Komitmen Organisasi terhadap Kinerja Karyawan: Studi pada Rumah Sakit Islam Banjarmasin. Jurnal Maksipreneur, 8(2), 191-206.

Dhermawan, A.A.N.B., Sudibya, I.G.A., \& Utama, I.W.M.U. (2012). Pengaruh Motivasi, Lingkungan Kerja, Kompetensi, Dan Kompensasi Terhadap Job Satisfaction dan Kinerja Pegawai di Lingkungan Kantor Dinas Pekerjaan Umum Provinsi Bali. Jurnal Manajemen, Strategi Bisnis, dan Kewirausahaan, 6(2), 173-184.

Luthans, F. (2006). Perilaku Organisasi Edisi Terjemahan. Yogyakarta: Andi.

Prasetyo, J. H., Ariawan, J., \& Ariyanto, E. (2021). An Excellent Strategy In Reducing Turnover Intention At Permata Keluarga Bekasi Hospital. International Journal of Scientific \& Technology Research, 10(01), 163-168. https://www.ijstr.org/finalprint/jan2021/An-Excellent-Strategy-In-Reducing-Turnover-Intention-At-PermataKeluarga-Bekasi-Hospital.pdf

Prastowo, I. (2015). Pengaruh Pengembangan Karir, Lingkungan Kerja dan Komitmen Organisasi terhadap Kepuasan Kerja Pegawai Hotel Sahid Jaya Solo dengan Keyakinan Diri (Self Effisasi) sebagai Variable pemoderasi. Jurnal Sainstech Politeknik Indonusa Surakarta, 1(3).

Rivai, V., \& Sagala, E.J. (2010). Manajemen Sumber Daya Manusia untuk Perusahaan dari Teori ke Praktik. Jakarta: PT Raja Grafindo.

Robbins, S.P. \& Judge, T.A. (2015). Perilaku Organisasi (Vol. Edisi 16). Jakarta: Salemba Empat.

Siagian, S.P. (2015). Manajemen Sumber Daya Manusia. Jakarta: PT Bumi Aksara.

Sutrisno. E. (2010). Manajemen Sumber Daya Manusia. Edisi Pertama. Cetakan Pertama. Jakarta: Penerbit Kencana. Gauzali Saydam.

Widodo. (2014). Manajemen Pengembangan Sumber Daya Manusia. Jakarta: Jaya Media.. Jakarta: Jaya Media. 